\title{
Patient Preferences to Undergo Low-Value CT Coronary Angiography in the Emergency Department
}

\author{
Jessica L. Winkels ${ }^{1}$ jwinkels@ med.umich.edu \\ Chelsea Morrow Smith ${ }^{1}$ cdmorrow@umich.edu
}

Rahul Iyengar ${ }^{1}$ iyengarr@umich.edu

Arjun P. Meka, MDªmeka@umich.edu

Jonathan D. Porath, MD² jporath@med.umich.edu

William J. Meurer, MD, MS ${ }^{2,3}$ wmeurer@med.umich.edu

${ }^{1}$ University of Michigan Medical School, Ann Arbor, MI

${ }^{2}$ Department of Emergency Medicine, University of Michigan Health System, Ann Arbor, MI

${ }^{3}$ Department of Neurology, University of Michigan Health System, Ann Arbor, MI

Address for Correspondence:

William J. Meurer, MD, MS

Department of Emergency Medicine

TC B1-354 1500 E. Medical Center Drive

Ann Arbor, MI 48109

wmeurer@med.umich.edu

Running Title: Patient preferences for low-value CTCA

Keywords (MESH): Traumatic/diagnostic imaging; Chest Pain/diagnostic imaging; Cross-

Sectional Studies; Diagnostic Tests, Routine/economics*;

Emergency Service, Hospital/economics

Word Count: 2444 


\section{$\underline{\text { Abstract }}$}

Background

32 Low-value diagnostic testing adds billions of dollars to the cost of health care in the US

33 annually. Addressing patient preference for these tests is one possible strategy to limit overuse.

34 In previous work, we showed that patient preference for testing can be influenced by test benefit,

35 risk, and financial measures. Our objective was to examine the effect of these variables in

36 another clinical scenario involving chest pain.

\section{Methods}

In this cross-sectional survey of patients at the University of Michigan Emergency Department (ED), participants were given a hypothetical scenario involving an ED visit for chest pain, along with information regarding potential benefit (detecting a life-threatening condition; 0.1 or $1 \%$ )

42 and risk (developing cancer; 0.1 or $1 \%$ ) of CTCA, as well as an incentive of $\$ 0$ or $\$ 100$ to forego

43 testing. Values for risk, benefit, and financial incentive varied across participants. Our primary

44 outcome was patient preference to undergo testing. We also obtained demographic and numeracy

45 information. Then, we used logistic regression to estimate odds ratios, adjusting for multiple

46 potential confounders. Our sample size was designed to find at least 300 events (test acceptance)

47 to allow for up to 30 covariates in fully adjusted models. We had $85-90 \%$ power to detect a $10 \%$

48 absolute difference in testing rate across groups, assuming a 95\% significance level.

\section{$50 \quad$ Results}

51913 patients were surveyed. A \$100 financial incentive (adjusted OR [AOR] 0.57; 95\%

52 Confidence Interval [CI] 0.42-0.78) and increased test risk (AOR 0.61; 95\% CI 0.44-0.84) both 
medRxiv preprint doi: https://doi.org/10.1101/19008391; this version posted October 18, 2019. The copyright holder for this preprint (which was not certified by peer review) is the author/funder, who has granted medRxiv a license to display the preprint in perpetuity.

All rights reserved. No reuse allowed without permission.

Patient preferences for low-value CTCA

53 significantly decreased test acceptance in fully adjusted models, whereas increased test benefit

54 significantly increased test acceptance (AOR 2.45; 95\% CI 1.79-3.36).

55

\section{Conclusions}

57 Offering a financial incentive deterred patients from accepting testing despite varying levels of

58 risk and benefit. In the context of previous work, we provide preliminary evidence supporting

59 that financial interventions may impact patient preference more than test risk and benefit. 
Patient preferences for low-value CTCA

Main Manuscript

Introduction

62 Overuse of diagnostic testing in low-risk patients contributes substantially to the rising cost of

63 health care. One study estimated that the total annual financial burden of defensive medicine in

64 the United States exceeded \$46 billion in 2008 alone, and it is likely that this figure has

65 continued to rise in proportion with the overall cost of health care. ${ }^{1}$ Furthermore, patients who undergo unnecessary diagnostic tests are still subject to the risks of testing when potential benefit

67 is limited. Computed Tomography Coronary Angiography (CTCA) is a diagnostic test has

68 clinical utility in determining the need for more invasive procedures in patients with chest pain

69 and has a high negative predictive value for ruling out anginal chest pain. ${ }^{2}$ While it is useful for

70 certain patients, CTCA also involves radiation exposure that has been associated with an

71 increased cancer risk. ${ }^{3}$

72

73 Addressing overuse of low-value testing can be difficult, in part because the term "low-value" is

74 often subjectively defined. Although there are clinical decision tools available for providers to

75 risk stratify patients, the potential risk and benefit of testing varies considerably among patients. ${ }^{4}$

76 Initiating discussions with patients regarding the benefits and risks of low-value testing to elicit

77 patient preference has emerged as a potential solution to decrease the use of unnecessary

78 diagnostic testing in the emergency department. There is also evidence to support that patients

79 may be responsive to financial information while making health care decisions, although this

80 continues to be debated and has yet been be fully described. ${ }^{5-9}$ 
medRxiv preprint doi: https://doi.org/10.1101/19008391; this version posted October 18, 2019. The copyright holder for this preprint (which was not certified by peer review) is the author/funder, who has granted medRxiv a license to display the preprint in perpetuity.

All rights reserved. No reuse allowed without permission.

Patient preferences for low-value CTCA

82 Our previous work on this topic demonstrated that increased financial cost to patients

83 significantly decreased their desire for low-value diagnostic testing with CTCA and Computed

84 Tomography (CT) head scans in hypothetical scenarios involving chest pain and minor traumatic

85 brain injury (TBI), respectively. ${ }^{7,9}$ A subsequent study focused solely on patient preferences for

86 CT head in minor TBI showed that a financial incentive for patients to forego low-value

87 diagnostic testing also significantly reduced patient preference for this test. ${ }^{6}$ While the influence

88 of test benefit and risk on patient decision-making was of mixed statistical significance in our

89 original work, these variables both achieved statistical significance in our CT head/minor TBI

90 study. 6,9

91

92 In this study, we investigated the effect of a direct financial incentive to forego low-value

93 diagnostic testing on patient preference to pursue diagnostic CTCA in a hypothetical scenario

94 involving low-risk chest pain in the context of varying levels of associated test benefit and risk.

95 Our aim in this study was to obtain further data to better characterize the effect of a financial

96 incentive - as well as varying levels of test benefit and risk - on patient preference across

97 another clinical scenario involving a different diagnostic test. We hypothesized that our results

98 would be comparable to our follow-up study involving minor TBI in that a financial incentive,

99 increased test risk, and decreased test benefit would all significantly deter patients from

100 accepting testing with low-value CTCA.

101

102 Methods

103 Overview 
medRxiv preprint doi: https://doi.org/10.1101/19008391; this version posted October 18, 2019. The copyright holder for this preprint (which was not certified by peer review) is the author/funder, who has granted medRxiv a license to display the preprint in perpetuity.

All rights reserved. No reuse allowed without permission.

Patient preferences for low-value CTCA

104 This study is a cross-sectional survey of a convenience sample of adult patients from the

105 University of Michigan Emergency Department (ED) designed to examine the potential effect of

106 financial incentive, test benefit, and test risk on patient preference for low-value diagnostic

107 testing with CTCA in the setting of chest pain. The current study reports a different outcome

108 based on previously reported methodology. ${ }^{6}$

Study Design

111 Study participants were presented with a hypothetical scenario in which they presented to the ED with low-risk chest pain, for which further testing with CTCA would not be clinically indicated. detect a life-threatening acute process; either 0.1 or $1 \%$ ) that would classify them as having a

115 HEART score in the low risk category. ${ }^{10}$

The full study scenario is available in Appendix A. Consent was obtained, and the scenario script was read aloud to all participants to minimize any issues they might have with reading, seeing, or understanding the scenario. Participants then were assigned a value for test benefit (detecting a life-threatening medical condition; either $0.1 \%$ or $1 \%$ ), test risk (the chance of developing cancer

121 due to radiation within 10 years; either $0.1 \%$ or $1 \%$ ), and financial incentive (a cash payment of

$122 \$ 0$ or $\$ 100$ from an insurance company to forego CTCA) prior to being asked for their

123 preference for or against testing. Values for test risk and benefit were represented as percentages, 124 ratios, and visual depictions (Appendix A) to facilitate participants' understanding. ${ }^{11,12}$ As in

125 previous work, these values for benefit, risk, and financial incentive were chosen because they

126 were thought to encompass the most interesting zone of variation in patient preference in a

\section{Page 6}


medRxiv preprint doi: https://doi.org/10.1101/19008391; this version posted October 18, 2019. The copyright holder for this preprint (which was not certified by peer review) is the author/funder, who has granted medRxiv a license to display the preprint in perpetuity.

Patient preferences for low-value CTCA

127 preliminary study performed by the authors. ${ }^{7}$ The risk values were also considered plausible

128 benefit and risk probabilities associated with diagnostic CTCA. ${ }^{13}$

\section{Setting and Population}

131 Our study used a convenience sample of 913 adult patients in the University of Michigan ED

132 who were not presenting with chest pain, recent head trauma, or altered mental status. No

133 patients in resuscitation bays or with contact precautions were approached. Participation was

134 voluntary, and participants were not offered financial compensation for participating.

\section{Human Subjects Protection}

137 The University of Michigan Institutional Review Board reviewed this study and determined it to be exempt survey research.

\section{Primary Outcomes and Variables}

141 Our primary outcome was the percentage of patients accepting diagnostic testing with CTCA 142 given the three major predictive variables: test benefit, test risk, and financial incentive. This

143 combination of variables resulted in eight possible subgroups. We obtained de-identified

144 demographic information and relevant past medical history to assess for potential confounders, 145 which were specified in advance. Confounders included age, gender, marital status, educational 146 status, race, ethnicity, income, prior medical training or employment, self-reported overall 147 health, and past medical history of cancer, hypertension, diabetes, atrial fibrillation, myocardial 148 infarction, or head trauma requiring a hospital visit. Numeracy was evaluated by a previously 
medRxiv preprint doi: https://doi.org/10.1101/19008391; this version posted October 18, 2019. The copyright holder for this preprint (which was not certified by peer review) is the author/funder, who has granted medRxiv a license to display the preprint in perpetuity.

All rights reserved. No reuse allowed without permission.

Patient preferences for low-value CTCA

149 validated assessment, and participants were classified as having low, medium, or high numeracy

150 accordingly. ${ }^{14}$

152 Data Collection

153 We used Qualtrics for survey administration and data collection, and we used SPSS (Armonk,

154 NY Version 25) for data analysis. All participant responses in which the primary outcome was

155 obtained were incorporated into the analysis. We compared the unadjusted proportion of

156 participants who chose to receive a CTCA for each combination of values for test benefit, test

157 risk, and financial incentive.

159 Sample Size

160 We followed methodology that was previously reported in our 2018 and 2019 work analyzing

161 the effect of an additional copayment or financial incentive for a diagnostic test, respectively. ${ }^{6,9}$

162 Our sample size of 913 conferred approximately $85-90 \%$ power to detect a $10 \%$ absolute change

163 in the proportion of subjects agreeing to testing from a baseline test acceptance rate of $50 \%$ at a

$16495 \%$ level of significance.

166 Data Analysis

167 We performed a series of nested multivariable logistic regression models to obtain the odds that

168 participants would agree to undergo a CTCA, given the variable combinations as noted above.

169 We adjusted for four sets of variables in the models, and all variables were specified in advance.

170 Variables were ordered so that those predicted to be more influential would be included in earlier

171 models. The fully adjusted model was limited to at most 30 variables in order to not exceed 10

\section{Page 8}


medRxiv preprint doi: https://doi.org/10.1101/19008391; this version posted October 18, 2019. The copyright holder for this preprint (which was not certified by peer review) is the author/funder, who has granted medRxiv a license to display the preprint in perpetuity. All rights reserved. No reuse allowed without permission.

Patient preferences for low-value CTCA

172 outcome events per predictor. Model 1 adjusted for the benefit, risk, and financial incentive 173 associated with testing. Model 2 additionally adjusted for income, education level, and

174 numeracy. Model 3 additionally adjusted for age, gender, race, ethnicity, and previous healthcare

175 training/employment. Finally, Model 4 additionally adjusted for self-reported overall health and

176 a medical history of cancer, hypertension, diabetes, atrial fibrillation, myocardial infarction, or

177 head trauma requiring a hospital visit. Model fit was evaluated by the Hosmer and Lemeshow

178 Goodness of Fit Statistic with a p value of $>0.05$ indicating adequate fit.

179 The deidentified dataset and model output (including all parameter estimates for the fully

180 adjusted models, and goodness of fit statistics) is posted in the University of Michigan

181 Institutional Data Repository (https://doi.org/10.7302/pnmm-4v40).

\section{Results}

913 patients met inclusion criteria and completed the primary outcome by submitting their preference regarding undergoing diagnostic testing with CTCA. These 913 participants' results were incorporated into the analysis. The median participant age was 46 years (interquartile range 30-60) with an absolute range of 18-92 years. Further demographic and medical characteristics are displayed in Table 1.

Patients agreed to undergo CTCA in $62.8 \%$ of scenarios (573 out of 913). Unadjusted patient

191 preferences in each of the eight subgroups, which account for all possible combinations of the 192 three predictor variables, are shown in Table 2. In the unadjusted models, we found that 193 increased test risk and a financial incentive to forego testing resulted in a statistically significant 194 decrease in odds of test acceptance, whereas increased test benefit increased patient preference 
medRxiv preprint doi: https://doi.org/10.1101/19008391; this version posted October 18, 2019. The copyright holder for this preprint (which was not certified by peer review) is the author/funder, who has granted medRxiv a license to display the preprint in perpetuity.

All rights reserved. No reuse allowed without permission.

Patient preferences for low-value CTCA

195 for testing (Table 3). Each of the adjusted models also demonstrated this relationship (Table 4),

196 suggesting that none of the variables incorporated into the adjusted models were confounders

197 influencing the observed effect of the major predictive variables on test acceptance.

198

199 The fully adjusted models (Table 4) indicated that the odds of patients accepting a CTCA was

200 significantly lower when patients were offered a \$100 financial incentive to forego testing, as

201 compared to when no incentive was offered (adjusted OR [AOR] 0.57; 95\% Confidence Interval

202 [CI $0.42-0.78$ ). Increasing test benefit from $0.1 \%$ to $1 \%$ resulted in a significant increase in odds

203 of test acceptance (AOR 2.45; 95\% CI 1.79-3.36), and increasing test risk from $0.1 \%$ to $1 \%$ was

204 associated with a significant decrease in odds of test acceptance (AOR 0.61; 95\% CI 0.44-0.84).

205

206 Discussion

207 This study examined the effect of test benefit, test risk, and a financial incentive on patient

208 preference for pursuing low-value CTCA for chest pain in the ED. We found that decreased test

209 benefit, increased test risk, and offering a financial incentive decreased patient preference for

210 testing in a statistically significant manner. These findings supplement our prior work by

211 providing further evidence that a financial intervention targeted at reducing patient preference for

212 low-value testing may be effective in influencing patients' decision-making. A financial

213 incentive thereby may help to decrease costs attributable to unnecessary diagnostic testing in the

214 ED. Additionally, our data provides further evidence to suggest that discussing benefits and risks

215 of diagnostic testing with patients can impact their preferences regarding low-value tests, even

216 when values for benefit and risk are low. 
medRxiv preprint doi: https://doi.org/10.1101/19008391; this version posted October 18, 2019. The copyright holder for this preprint (which was not certified by peer review) is the author/funder, who has granted medRxiv a license to display the preprint in perpetuity. All rights reserved. No reuse allowed without permission.

Patient preferences for low-value CTCA

218 These results are particularly interesting in the context of our prior study in 2018, which

219 evaluated the impact of benefit, risk, and out-of-pocket cost on patient preference for low-value

220 CTCA in a similar hypothetical low-risk chest pain scenario. ${ }^{9}$ In the current study, there was a

$221 \quad 19.2 \%$ drop in test acceptance (72.3\% to 53.1\%) with decreased test benefit, a 9.1\% drop (67.3\%

222 to $58.2 \%)$ with increased risk, and a $10.1 \%$ drop (67.8\% to $57.7 \%)$ with a financial incentive. In

223 the 2018 work, we observed a similar trend in the data - there was a $9.4 \%$ drop $(74.3 \%$ to

$22465.0 \%)$ in test acceptance with decreased benefit, a $1.5 \%$ drop $(70.4 \%$ to $68.9 \%)$ with increased

225 risk, and a $22 \%$ drop (80.8\% to $58.7 \%$ ) with increased cost to the patient, although only the

226 effects of benefit and cost reached statistical significance. Additionally, the results of our current

227 study were congruent with our more recent study that analyzed the effect of test benefit, test risk,

228 and financial incentive on patient preference for low-value diagnostic testing with CT head in a

229 minor TBI scenario. ${ }^{6}$ This supports that the relationship between these variables may be

230 observed across multiple clinical situations.

231

232 Overall, the consistent effect of a financial intervention across all three studies provides

233 preliminary evidence to suggest that a financial strategy may be effective in modulating patients'

234 preferences regarding low-value diagnostic testing in the ED. Furthermore, while varying test

235 risk and benefit did influence patients' odds of test acceptance, these variables were not

236 statistically significant in all three studies. This suggests that a financial approach may be more

237 effective in influencing patient preferences than discussing the risks and benefits of testing alone.

238 Further study will be required to better describe the relationship between these variables and

239 patient preferences, as well as to comment on the generalizability of our findings in clinical

240 scenarios beyond low-risk chest pain and minor TBI. 
medRxiv preprint doi: https://doi.org/10.1101/19008391; this version posted October 18, 2019. The copyright holder for this preprint (which was not certified by peer review) is the author/funder, who has granted medRxiv a license to display the preprint in perpetuity.

All rights reserved. No reuse allowed without permission.

Patient preferences for low-value CTCA

Limitations

243 There are several limitations that should be considered when interpreting our results. First, we

244 surveyed ED patients using a hypothetical clinical scenario that was intentionally different from

245 their presenting chief complaint. Patients experiencing chest pain in the ED may be influenced

246 differently by our predictor variables. Additionally, the hypothetical scenario in our study

247 provided numeric representations of benefit and risk, whereas an individual patient's actual

248 benefit and risk for a particular test may not be easily quantifiable in this way. True risk of

249 CTCA may be lower than the percentages assigned in these scenarios, but $0.1 \%$ and $1 \%$ were

250 selected to maintain symmetry with values for potential benefit. Our study also cannot account

251 for the varying levels of medical knowledge or past exposure to health care that may have

252 affected patients' decision-making, even though participants were instructed to only consider the

253 numeric values for benefit and risk. Furthermore, as with prior studies, these hypothetical

254 scenarios required patients to consider the benefit of detecting an acute medical condition against

255 the risk of an adverse outcome far in the future - different time of onset for benefit and risk may

256 have also influenced patients' decisions. Finally, while we have now shown that a financial

257 incentive is associated with a statistically significant decrease in test acceptance in two distinct

258 clinical scenarios, this may not be generalizable outside the context of a low-risk, low-value test.

259 Patients may also make decisions differently if a test is designed to detect a medical condition

260 that is not life-threatening.

261

262 Conclusions 
medRxiv preprint doi: https://doi.org/10.1101/19008391; this version posted October 18, 2019. The copyright holder for this preprint (which was not certified by peer review) is the author/funder, who has granted medRxiv a license to display the preprint in perpetuity.

All rights reserved. No reuse allowed without permission.

Patient preferences for low-value CTCA

263 This cross-sectional survey of patients in the ED suggests that a financial incentive may be

264 effective in dissuading patients from accepting low-value testing with CTCA in the context of

265 low-risk chest pain. Given that this effect was also observed in a separate clinical scenario in our

266 prior study with similar methodology, it is possible that offering a financial incentive may be an

267 effective deterrent against patient preference for low-value testing across several distinct clinical

268 scenarios. Lower test benefit and higher test risk also significantly decreased patient preference

269 for testing in this study; however, these variables have not consistently emerged as statistically

270 significant factors in our previous work, whereas financial interventions have been statistically

271 significant throughout. Taken together, the findings in these studies suggest that a financial

272 approach may be more effective in influencing patient preference for low-value diagnostic

273 testing than discussion of test benefit and risk alone. Further study is needed to better

274 characterize the effect of each of these factors on patient preferences in additional clinical

275 scenarios and in a non-hypothetical setting.

276 
Patient preferences for low-value CTCA

\section{References}

1. Mello, M. M., Chandra, A., Gawande, A. A. and Studdert, D. M., National Costs Of The Medical Liability System, Health Affairs, 2010, 29(9):1569-1577.

2. Moss, A. J. and Newby, D. E., CT coronary angiographic evaluation of suspected anginal chest pain, Heart, 2015, 102(4):263-268.

3. Berrington de González, A., Projected Cancer Risks From Computed Tomographic Scans Performed in the United States in 2007, Archives of Internal Medicine, 2009, 169(22):2071.

4. Polaris, J. J. Z. and Katz, J. N., "Appropriate" diagnostic testing: supporting diagnostics with evidence-based medicine and shared decision making, BMC Research Notes, 2014, 7(1):922.

5. Giuffrida, A. and Torgerson, D. J., Should we pay the patient? Review of financial incentives to enhance patient compliance, BMJ, 1997, 315(7110):703-707.

6. Iyengar, R., Winkels, J. L., Smith, C. M., Meka, A. P., Porath, J. D. and Meurer, W. J., The Effect of Financial Incentives on Patient Decisions to Undergo Low-value Head Computed Tomography Scans, Academic Emergency Medicine, 2019, 0(0).

7. Meka, A. P., Porath, J. D., Iyengar, R., Morrow, C., Fagerlin, A. and Meurer, W. J., Risk, Benefit, and Cost Thresholds for Emergency Department Testing: A Cross-sectional, Scenariobased Study, Academic Emergency Medicine, 2017, 24(6):686-690.

8. Moriates, C., Shah, N. T. and Arora, V. M., First, Do No (Financial) Harm, JAMA, 2013, 310(6):577.

9. Porath, J. D., Meka, A. P., Morrow, C., Iyengar, R., Shtull $\square$ Leber, E., Fagerlin, A. and Meurer, W. J., Patient Preferences for Diagnostic Testing in the Emergency Department: A Cross $\square$ sectional Study, Academic Emergency Medicine, 2018, 25(6):627-633. 
medRxiv preprint doi: https://doi.org/10.1101/19008391; this version posted October 18, 2019. The copyright holder for this preprint (which was not certified by peer review) is the author/funder, who has granted medRxiv a license to display the preprint in perpetuity. All rights reserved. No reuse allowed without permission.

Patient preferences for low-value CTCA

299 10. Backus, B. E., Six, A. J., Kelder, J. C., Bosschaert, M. A. R., Mast, E. G., Mosterd, A.,

300 Veldkamp, R. F., et al., A prospective validation of the HEART score for chest pain patients at

301 the emergency department, International Journal of Cardiology, 2013, 168(3):2153-2158.

302 11. Brust-Renck, P. G., Royer, C. E. and Reyna, V. F., Communicating Numerical Risk,

303 Reviews of Human Factors and Ergonomics, 2013, 8(1):235-276.

304 12. Schapira, M. M., Nattinger, A. B. and McAuliffe, T. L., The Influence of Graphic Format on 305 Breast Cancer Risk Communication, Journal of Health Communication, 2006, 11(6):569-582.

306 13. Brenner, D. J. and Hall, E. J., Computed Tomography - An Increasing Source of Radiation

307 Exposure, New England Journal of Medicine, 2007, 357(22):2277-2284.

308 14. Fagerlin, A., Zikmund-Fisher, B. J., Ubel, P. A., Jankovic, A., Derry, H. A. and Smith, D.

309 M., Measuring Numeracy without a Math Test: Development of the Subjective Numeracy Scale, 310 Medical Decision Making, 2007, 27(5):672-680. 
Table 1: Characteristics of Study Participants ( $N$ = 913)

\begin{tabular}{|c|c|}
\hline Characteristic & $\%(n)$ \\
\hline \multicolumn{2}{|l|}{ Age, years } \\
\hline $18-25$ & $16 \%(146)$ \\
\hline $26-40$ & $23.1 \%(211)$ \\
\hline $41-55$ & $25.6 \%(234)$ \\
\hline $56-65$ & $15.0 \%(137)$ \\
\hline $66-75$ & $10.7 \%(98)$ \\
\hline$>76$ & $5.1 \%(47)$ \\
\hline Unreported & $4.4 \%(40)$ \\
\hline \multicolumn{2}{|l|}{ Sex } \\
\hline Male & $39.6 \%(362)$ \\
\hline Female & $56.1 \%(512)$ \\
\hline Other/Transgender & $0.1 \%(1)$ \\
\hline Unreported & $4.1 \%(38)$ \\
\hline \multicolumn{2}{|l|}{ Marital status } \\
\hline Married & $49.8 \%(455)$ \\
\hline Divorced & $7.6 \%(69)$ \\
\hline Single/never married & $32.0 \%(292)$ \\
\hline Separated & $1.2 \%(11)$ \\
\hline Widowed & $5.0 \%(46)$ \\
\hline Unreported & $4.4 \%(40)$ \\
\hline \multicolumn{2}{|l|}{ Highest level of education } \\
\hline Some high school & $3.9 \%(36)$ \\
\hline High school graduate & $15.4 \%(141)$ \\
\hline Some college & $31.5 \%(288)$ \\
\hline College graduate & $26.4 \%(241)$ \\
\hline Post-graduate & $16.1 \%(147)$ \\
\hline Unreported & $6.6 \%(60)$ \\
\hline Works in healthcare & $24.5 \%(224)$ \\
\hline Hispanic & $5.3 \%(48)$ \\
\hline \multicolumn{2}{|l|}{ Race } \\
\hline American Indian/Alaska Native & $0.5 \%(5)$ \\
\hline African American & $12.0 \%(110)$ \\
\hline Caucasian & $77.1 \%(704)$ \\
\hline Asian & $2.1 \%(19)$ \\
\hline Native Hawaiian/Pacific Islander & $0.2 \%(2)$ \\
\hline Other & $2.0 \%(18)$ \\
\hline Prefer not to disclose/Unreported & $6.0 \%(55)$ \\
\hline History of cancer & $13.2 \%(120)$ \\
\hline History of diabetes & $15.1 \%(137)$ \\
\hline History of hypertension & $29.2 \%(264)$ \\
\hline History of atrial fibrillation & $7.7 \%(70)$ \\
\hline History of heart attack & $5.0 \%(45)$ \\
\hline History of head injury requiring ED visit & $20.5 \%(184)$ \\
\hline \multicolumn{2}{|l|}{ Self-reported overall health } \\
\hline Excellent & $10.6 \%(97)$ \\
\hline Very good & $26.2 \%(239)$ \\
\hline Good & $28.3 \%(258)$ \\
\hline Fair & $18.4 \%(168)$ \\
\hline Poor & $9.1 \%(83)$ \\
\hline Unreported & $7.5 \%(68)$ \\
\hline \multicolumn{2}{|l|}{ Household income level } \\
\hline Less than $\$ 10,000$ & $5.1 \%(47)$ \\
\hline$\$ 10,000-\$ 14,999$ & $2.8 \%(26)$ \\
\hline
\end{tabular}


medRxiv preprint doi: https://doi.org/10.1101/19008391; this version posted October 18, 2019. The copyright holder for this preprint (which was not certified by peer review) is the author/funder, who has granted medRxiv a license to display the preprint in perpetuity.

All rights reserved. No reuse allowed without permission.

\begin{tabular}{|l|c|}
\hline$\$ 15,000-\$ 24,999$ & $3.6 \%(33)$ \\
$\$ 25,000-\$ 34,999$ & $7.3 \%(67)$ \\
$\$ 35,000-\$ 49,999$ & $6.0 \%(55)$ \\
$\$ 50,000-\$ 74,999$ & $9.7 \%(89)$ \\
$\$ 75,000-\$ 99,999$ & $7.4 \%(68)$ \\
$\$ 100,000-\$ 149,999$ & $10.0 \%(91)$ \\
$\$ 150,000-\$ 199,999$ & $3.2 \%(29)$ \\
$\$ 200,000$ or more & $5.4 \%(49)$ \\
Unreported/Prefer not to disclose & $39.3 \%(359)$ \\
\hline
\end{tabular}


medRxiv preprint doi: https://doi.org/10.1101/19008391; this version posted October 18, 2019. The copyright holder for this preprint (which was not certified by peer review) is the author/funder, who has granted medRxiv a license to display the preprint in perpetuity.

All rights reserved. No reuse allowed without permission.

Table 2: Patient Preferences by Subgroup

Incentive $=\$ 0$

\begin{tabular}{|c|c|c|c|}
\hline & & \multicolumn{2}{|c|}{ Risk } \\
\hline \multirow{3}{*}{ Benefit } & & $0.1 \%$ & $1 \%$ \\
\hline & $0.1 \%$ & $\begin{array}{l}\text { Accept Test: } 66.1 \% \\
\text { (74 of } 112 \text { ) }\end{array}$ & $\begin{array}{l}\text { Accept Test: } 48.7 \% \\
\text { (58 of 119) }\end{array}$ \\
\hline & $1 \%$ & $\begin{array}{l}\text { Accept Test: } 86.6 \% \\
\text { (84 of } 97)\end{array}$ & $\begin{array}{l}\text { Accept Test: } 72.5 \% \\
\text { (95 of 131) }\end{array}$ \\
\hline
\end{tabular}

Incentive $=\$ 100$

\begin{tabular}{|c|c|l|l|}
\hline & \multicolumn{3}{|c|}{ Risk } \\
\hline \multirow{4}{*}{ Benefit } & & \multicolumn{1}{|c|}{$\mathbf{0 . 1 \%}$} & \multicolumn{1}{|c|}{$\mathbf{1 \%}$} \\
\cline { 2 - 4 } & $\mathbf{0 . 1 \%}$ & $\begin{array}{l}\text { Accept Test: 53.9\% } \\
\text { (69 of 128) }\end{array}$ & $\begin{array}{l}\text { Accept Test: 42.7\% } \\
\text { (41 of 96) }\end{array}$ \\
\cline { 2 - 4 } & $\mathbf{1 \%}$ & $\begin{array}{l}\text { Accept Test: 67.2\% } \\
\text { (80 of 119) }\end{array}$ & $\begin{array}{l}\text { Accept Test: 64.9\% } \\
\text { (72 of 111) }\end{array}$ \\
\hline
\end{tabular}




\section{Table 3: Unadjusted Patient Preferences}

\begin{tabular}{|l|l|}
\hline & $\%(\mathrm{n})$ accepting test \\
\hline Benefit & \\
$0.1 \%($ ref $)$ & $53.1 \%(242)$ \\
$1 \%$ & $72.3 \%(331)$ \\
OR (CI 95\%) & $2.287(1.738-3.008)$ \\
\hline Risk & $67.3 \%(307)$ \\
$0.1 \%($ ref) & $58.2 \%(226)$ \\
$1 \%$ & $0.673(0.514-0.882)$ \\
OR (CI 95\%) & $67.8 \%(311)$ \\
\hline Incentive & $57.7 \%(262)$ \\
$\$ 0($ ref $)$ & $0.647(0.494-0.847)$ \\
$\$ 100$ & $62.8 \%(573$ of 913) \\
OR (CI 95\%) & \\
\hline Total & \\
\hline
\end{tabular}

* $\mathrm{OR}=$ odds ratio $; \mathrm{CI}=$ confidence interval All odds ratios are unadjusted 
medRxiv preprint doi: https://doi.org/10.1101/19008391; this version posted October 18, 2019. The copyright holder for this preprint (which was not certified by peer review) is the author/funder, who has granted medRxiv a license to display the preprint in perpetuity.

All rights reserved. No reuse allowed without permission.

Table 4: Nested Logistic Regression Model ${ }^{*}$

\begin{tabular}{|l|l|l|l|l|}
\hline & $\begin{array}{l}\text { Model 1 } \\
\text { AOR (95\% CI) }\end{array}$ & $\begin{array}{l}\text { Model 2 } \\
\text { AOR (95\% CI) }\end{array}$ & $\begin{array}{l}\text { Model 3 } \\
\text { AOR (95\% CI) }\end{array}$ & $\begin{array}{l}\text { Model 4 } \\
\text { AOR (95\% CI) }\end{array}$ \\
\hline $\begin{array}{l}\text { Benefit } \\
(1 \% \text { vs. 0.1\%) }\end{array}$ & $2.42(1.83-3.20)$ & $2.47(1.82-3.35)$ & $2.42(1.78-3.29)$ & $2.45(1.79-3.36)$ \\
\hline $\begin{array}{l}\text { Risk } \\
(1 \% \text { vs. 0.1\%) }\end{array}$ & $0.60(0.45-0.79)$ & $0.61(0.45-0.83)$ & $0.60(0.44-0.82)$ & $0.61(0.44-0.84)$ \\
\hline $\begin{array}{l}\text { Incentive } \\
(\$ 100 \text { vs } \$ 0)\end{array}$ & $0.60(0.45-0.79)$ & $0.57(0.42-0.77)$ & $0.58(0.43-0.79)$ & $0.57(0.42-0.78)$ \\
\hline
\end{tabular}

\footnotetext{
* Model 1 adjusts for benefit, risk, and incentive associated with testing. Model 2 additionally adjusts for income, education level, and numeracy. Model 3 additionally adjusts for age, gender, race, ethnicity, and previous healthcare training or employment. Model 4 additionally adjusts for self-reported overall health and a medical history of cancer, hypertension, diabetes, atrial fibrillation, myocardial infarction, and head trauma requiring hospital visit. Hosmer and Lemeshow Goodness of Fit p-value ranged from 0.9 to 0.3 , indicating that model fit was adequate. $\mathrm{AOR}=$ adjusted odds ratio; $\mathrm{CI}=$ confidence interval.
} 